International Journal of Business Management and Economic Review

Vol. 4, No. 04; 2021

ISSN: 2581-4664

\title{
THE ROLE OF JOB SATISFACTION MEDIATION TO THE RELATIONSHIP BETWEEN COMPENSATION AND PERFORMANCE
}

\author{
Riduansah, Djoko Setyadi, Eny Rochaida, Ariesta Heksarini and Meiki Permana \\ Faculty of Economics and Business, Mulawarman University, Samarinda, Indonesia
}

http://doi.org/10.35409/IJBMER.2021.3302

\begin{abstract}
Improvement of Employee Performance can not be separating from the factors of Job Satisfaction and Compensation. This study aims to analyze the mediation role of Job Satisfaction in Compensation to Employee Performance relationship. They are using Structural Equation Modeling and with data from 250 Employee Respondents. Analysis Results, Compensation positively and significantly correlated to Job Satisfaction and Performance. Job Satisfaction positively and significantly correlated to performance. The role of complete mediation of Job Satisfaction to the relationship between Compensation and Performance proves that compensation must first improve Job Satisfaction to achieve performance improvement. Human Resource Managers in each Company to improve Employee Performance using compensation strategies to improve Job Satisfaction.
\end{abstract}

Keyword: Compensation, Job Satisfaction, Performance, Structural Equation Modeling.

\section{INTRODUCTION}

The performance of employees, especially employees who work as civil servants aims to ensure the objectivity of the development of Civil Servants based on the performance system and career system. The realization of a world-class government needs to be supported by ministries, institutions, and provincial and district governments. In bureaucratic reform, three aspects are to achieve: the realization of a clean government from Corruption, collusion, nepotism, the realization of improved public services, and improving the quality and accountability of Bureaucracy. In the Book entitled "Controlling Bureaucratic Corruption" (Gong \& Yang, 2019), Corruption causes losses to state coffers, undermines the supremacy regime of law and regulation, distorts the provision of public services, undermines public trust in the government, and undermines the quality of government as a whole. According to (Herawaty 2018), Bureaucracy as a system of organizing state apparatus with an extensive and complex task is necessary for controlling government running.

However, the Performance of Bureaucracy and the routine activities of officials and bureaucratic officials cause new problems.. This situation often raises the potential for maladministration practices in the practice of Corruption, collusion, nepotism, and the decline of public services. Departing from such bureaucratic conditions, bureaucratic reform and good governance become the main pillars and central points in realizing the Management of State Civil Apparatus become necessary for a world-class bureaucracy. 
In today's increasingly competitive environment, the organization recognizes the internal human element as a fundamental source of improvement. On the one hand, managers concentrate on employee well-being, desires, needs, goals, and personal desires to understand job satisfaction. Moreover, managers make organizational decisions based on employee performance(Muna et al., 2017), so naturally, a two-way relationship forms a cyclical causeand-effect relationship. Satisfaction leads to Performance, and Performance leading to satisfaction through several mediation factors. The same is said by (Cedaryana et al., 2018)(Barasa et al., 2018), that job satisfaction positively affects employee performance.

In addition to Job Satisfaction, Compensation is also a determining factor of Employee Performance. As conveyed by (Indrasari et al., 2019)and(Nanda et al., 2020), compensation significantly affects employee performance.

Create a Professional Bureaucracy, as well as perform well. This study will analyze the Performance of Bureaucratic Employees who work in the Government of Samarinda City, East Kalimantan, Indonesia. The exogenous factor is compensation and the mediation role of Job Satisfaction.

\section{LITERATURE REVIEW}

Performance may be affected by Work Satisfaction. According to (Ajzen 1991), individual attitude towards job satisfaction affects their performance; increasingly dissatisfied individuals, the lower the Performance(Bies \& Organ, 1989). Workersare motivated by something outside of themselves, such as money and status, or internal, such as compensation. Social-cognitive theory and social exchange theory are two theories that discuss the relationship between Job Satisfaction and Performance. In contrast, Equity Theory(Adams, 1963), base on the idea that individuals are motivated by justice.

The results of studies are delivered by (Baledi \& Saed, 2017), compensation directly affects employee performance and job satisfaction, and job satisfaction directly affects employee performance. At the same time, the influence of compensation on employees through job satisfaction is negative. In this case, job satisfaction does not act as a mediator between compensation and employee performance. Employees are more interested in financial and non-financial compensation by giving employees more bonuses and annual bonuses that provide the employee with job satisfaction, leading to higher performance. The same research was delivered by (Saputra et al., 2018), that Job satisfaction cannot mediate the relationship between Compensation and Performance.A study delivered by (Rosalia et al., 2020)that compensation has a significant negative effect on job satisfaction, and compensation has an insignificant positive effect on employee performance. As for indirect influence, compensation results do not significantly negatively affect employee performance through job satisfaction as an intervening variable.

Different studies are delivered by (Sherly et al., 2021)that compensation also significantly affects job satisfaction and performance, and job satisfaction mediates the relationship between Compensation to Performance. 


\section{CONCEPTUAL FRAMEWORK AND RESEARCH HYPOTHESIS}

The Conceptual Framework of the Research Model can see in Figure 1.

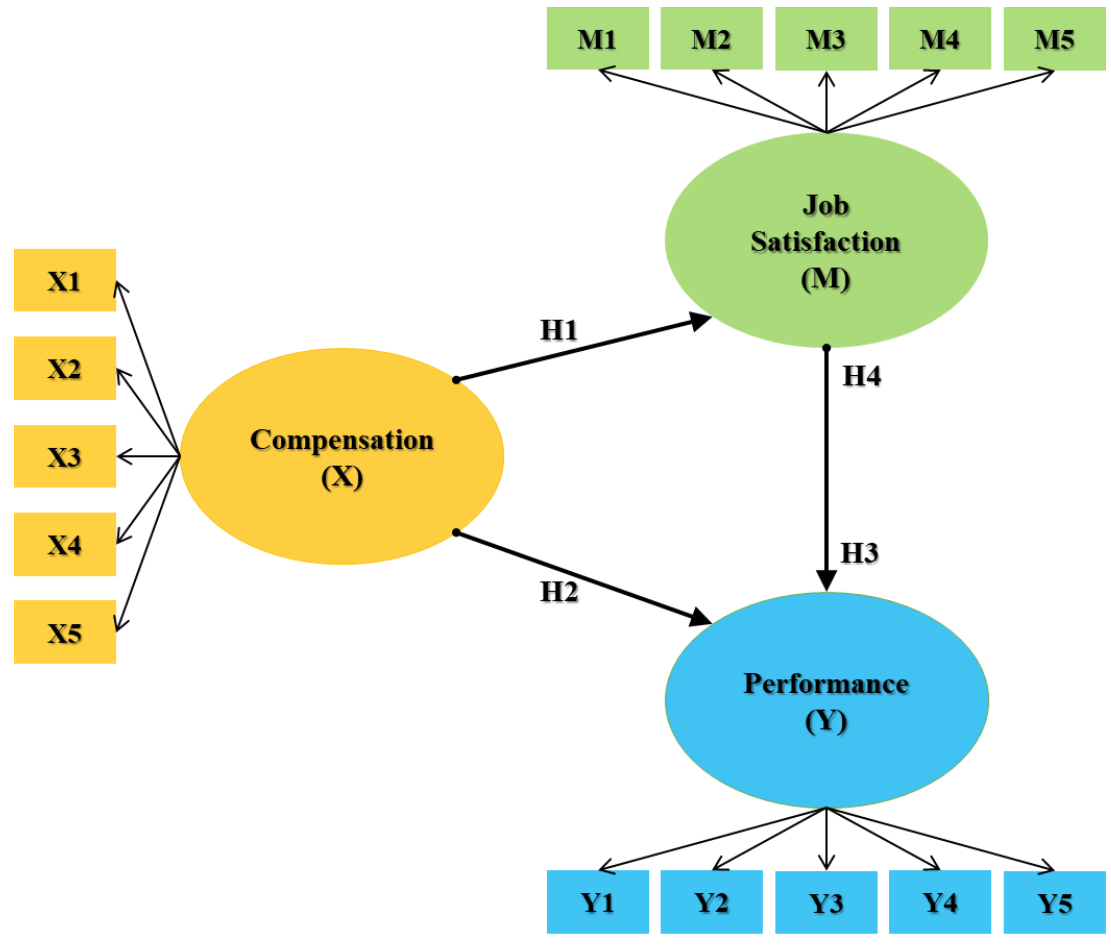

Figure 1. Conceptual Framework and Research Hypothesis

Description of Notation:

Compensation (X)

$\mathrm{X} 1$ : feeling enough with the additional income allowance I receive each month.

$\mathrm{X} 2$ : Very happy with the 13th salary given by the government because it can help the needs of the beginning of the school year.

X3: Very happy with the awarding of 14 salaries as a holiday allowance.

X4: Very happy with the honor of the team that can add additional income.

X5: Happy to participate in training; it can support performance.

Job Satisfaction (M)

M1: Enjoy the work that exists today.

M2: Work is in line with abilities.

M3: Excel promoting.

M4: Enjoy working with coworkers.

M5: strongly supported by the boss.

Performance (Y) 
International Journal of Business Management and Economic Review

Vol. 4, No. 04; 2021

ISSN: 2581-4664

Y1: The orientation of subordinatesis satisfactory.

Y2: Subordinates have high integrity.

Y3: Subordinates are committed to their work.

Y4: Subordinates have discipline in their work.

Y5: Subordinates have good cooperation.

Hypothesis 1 (H1): Compensation has a Positive and Significant Impact on Job Satisfaction. Hypothesis 2 (H2): Compensation has a Positive and Significant Impact on Performance. Hypothesis 3 (H3): WorkSatisfaction has a Positive and Significant Impact on Performance. Hypothesis 4 (H4): Job Satisfaction mediates the relationship between Compensation to Performance.

\section{STRUCTURAL EQUATION MODELING (SEM)}

Structural Equation Modeling (SEM) can see in Figure 2.

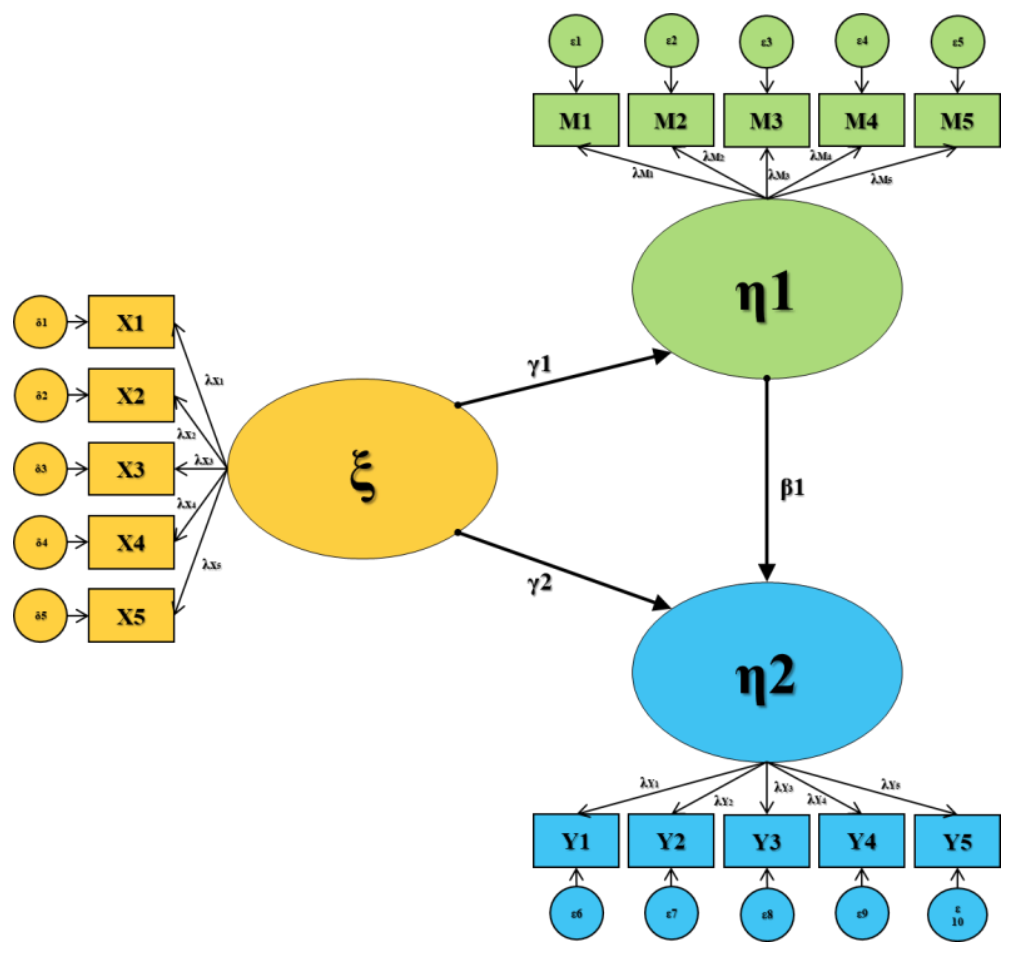

Figure 2. Structural Equation Modeling (SEM)

Notations used in Structural Equation Modeling (SEM):

$\xi$ : Exogenous Latent Variables (Compensation).

$\eta 1$ : Endogenous Latent Variables (Job Satisfaction). 
International Journal of Business Management and Economic Review

Vol. 4, No. 04; 2021

ISSN: 2581-4664

१2: Endogenous Latent Variables (Performance).

$\delta$ : Measurement error on the manifest variable for Exogenous latent variable.

$\varepsilon:$ Measurement error on the manifest variable for latent variable Endogene.

$\gamma$ : Coefficient of influence of exogenous variables on endogenous variables.

$\beta$ : Coefficient of influence of endogenous variables on endogenous variables.

Outer Model Equation:

Compensation (X) or $(\xi)$ :

$\mathrm{X} 1=\lambda \mathrm{X} 1 \xi+\delta 1$

$\mathrm{X} 2=\lambda \mathrm{X} 2 \xi+\delta 2$

$\mathrm{X} 3=\lambda \mathrm{X} 3 \xi+\delta 3$

$\mathrm{X} 4=\lambda \mathrm{X} 4 \xi+\delta 4$

$\mathrm{X} 5=\lambda \mathrm{X} 5 \xi+\delta 5$

Job Satisfaction (M) or ( $\eta 1)$ :

$\mathrm{M} 1=\lambda \mathrm{M} 1 \eta 1+\varepsilon 1$

$\mathrm{M} 2=\lambda \mathrm{M} 2 \eta 1+\varepsilon 2$

$\mathrm{M} 3=\lambda \mathrm{M} 3 \eta 1+\varepsilon 3$

$\mathrm{M} 4=\lambda \mathrm{M} 4 \eta 1+\varepsilon 4$

$\mathrm{M} 5=\lambda \mathrm{M} 5 \eta 1+\varepsilon 5$

Performance $(Y)$ or $(\eta 2)$ :

$\mathrm{Y} 1=\lambda \mathrm{Y} 1 \eta 2+\varepsilon 6$

$\mathrm{Y} 2=\lambda \mathrm{Y} 2 \eta 2+\varepsilon 7$

$\mathrm{Y} 3=\lambda \mathrm{Y} 3 \eta 2+\varepsilon 8$

$\mathrm{Y} 4=\lambda \mathrm{Y} 4 \eta 2+\varepsilon 9$

$\mathrm{Y} 5=\lambda \mathrm{Y} 5 \eta 2+\varepsilon 10$

Inner Model Equation:

Job Satisfaction $(\mathrm{M})$ or $(\eta 1)=\gamma 1 \xi 1+\xi 1$

Performance $(Y)$ or $(\eta 2)=\gamma 2 \xi 1+\beta 1 \eta 1+\xi 2$

\section{METHODS}

This study describes the causal relationship between variables (explanatory research), a study to know and explain the influence between existing variables, and continued testing of 4 (four) hypotheses.This research is also affirmative because this research was conducted to test conceptual models of theoretical and empirical research.

In this study, respondents in Samarinda City Hall served in the regional device organization of the Regional Education and Training Staffing Agency. The Regional Revenue Agency. The Regional Research and Development Agency, the National Unity and Political Agency, and the Regional Financial and Asset Management Agency in the Samarinda City Government environment, with the criteria of civil servants who have administrative and functional positions.The population in this study was 415 people, and the sample count was 250 respondents. Using Structural Equation Modeling and analyzed using the WarpPLS program. 


\section{International Journal of Business Management and Economic Review}

Vol. 4, No. 04; 2021

ISSN: 2581-4664

In the process of multivariate analysis, the relationship between variables is also in the calculation process. Interpretation of the analysis results made comprehensively, and this is in harmony with the nature that multivariate analysis already considers the relationship between variables.

Using variance-based and factor-based structural equation models (SEM), using the least-squares and factor-based methods. (Kock, 2015b)(Kock, 2015a). There is a ten model fit and quality index(Kock, 2010)(Kock, 2014)(Kock, 2015c), as follows (refer to Table 1):

Table 1. Model fit and quality index

\begin{tabular}{|l|l|l|}
\hline No & Model fit \& Quality index & Criteria Fit \\
\hline 1 & Average Path Coefficient (APC) & $\mathrm{p}<0.001$ \\
\hline 2 & Average R-squared (ARS) & $\mathrm{p}<0.001$ \\
\hline 3 & Average Adjusted R-squared (AARS) & $\mathrm{p}<0.001$ \\
\hline 4 & $\begin{array}{l}\text { Average block Variance Inflation Factor } \\
\text { (AVIF) }\end{array}$ & Acceptable if $\leq 5$ \\
\cline { 3 - 3 } 5 & Average Full Collinearity VIF (AFVIF) & Acceptable if $\leq 5$ \\
\cline { 3 - 3 } & \multirow{2}{*}{6} & Ideally $\leq 3.3$ \\
\hline \multirow{2}{*}{7} & TenenhausGoF (GoF) & Small $\geq 0.1$ \\
\cline { 3 - 3 } & & Medium $\geq 0.25$ \\
\hline \multirow{2}{*}{8} & Simpson's paradox ratio (SPR) & Large $\geq 0.36$ \\
\cline { 3 - 3 } & R-squared contribution ratio (RSCR) & Ideally $=1$ \\
\hline 9 & Statistical suppression ratio (SSR) & Acceptable if $\geq 0.7$ \\
\cline { 3 - 3 } 10 & $\begin{array}{l}\text { Nonlinear- bivariate causality- direction ratio } \\
\text { (NLBCDR) }\end{array}$ & Ideally $=1$ \\
\hline
\end{tabular}

\section{RESULTS ANDDISCUSSION}

Table 2. Composite reliability coefficients, Cronbach's alpha coefficients, Average variances extracted (AVE)

\begin{tabular}{|l|c|c|c|}
\hline Latent Variables & $\begin{array}{c}\text { Composite reliability } \\
\text { coefficients }\end{array}$ & $\begin{array}{c}\text { Cronbach's alpha } \\
\text { coefficients }\end{array}$ & $\begin{array}{c}\text { Average variances } \\
\text { extracted (AVE) }\end{array}$ \\
\hline Compensation $(\mathrm{X})$ & 0.967 & 0.957 & 0.854 \\
\hline Job Satisfaction $(\mathrm{M})$ & 0.963 & 0.951 & 0.838 \\
\hline Performance $(\mathrm{Y})$ & 0.941 & 0.920 & 0.762 \\
\hline
\end{tabular}


International Journal of Business Management and Economic Review

Vol. 4, No. 04; 2021

ISSN: 2581-4664

Table 3. Analysis Results Model fit and quality index

\begin{tabular}{|c|c|c|c|c|}
\hline No & $\begin{array}{l}\text { Model fit \& Quality } \\
\text { index }\end{array}$ & Criteria Fit & $\begin{array}{l}\text { Analysis } \\
\text { results }\end{array}$ & Remarks \\
\hline 1 & $\begin{array}{l}\text { Average Path } \\
\text { Coefficient (APC) }\end{array}$ & $\mathrm{p}<0.001$ & $\begin{array}{l}0.536 \\
p<0.001\end{array}$ & $\begin{array}{l}\text { Good } \\
\text { Significant }\end{array}$ \\
\hline 2 & $\begin{array}{l}\text { Average R-squared } \\
\text { (ARS) }\end{array}$ & $\mathrm{p}<0.001$ & $\begin{array}{l}0.581 \\
p<0.001\end{array}$ & $\begin{array}{l}\text { Good } \\
\text { Significant }\end{array}$ \\
\hline 3 & $\begin{array}{l}\text { Average Adjusted R- } \\
\text { squared (AARS) }\end{array}$ & $\mathrm{p}<0.001$ & $\begin{array}{l}0.579 \\
p<0.001\end{array}$ & $\begin{array}{l}\text { Good } \\
\text { Significant }\end{array}$ \\
\hline \multirow[b]{2}{*}{4} & \multirow{2}{*}{$\begin{array}{l}\text { Average block } \\
\text { Variance Inflation } \\
\text { Factor (AVIF) }\end{array}$} & Acceptable if $\leq 5$ & & \\
\hline & & Ideally $\leq 3.3$ & 1.435 & Ideal \\
\hline \multirow[b]{2}{*}{5} & \multirow{2}{*}{$\begin{array}{l}\text { Average Full } \\
\text { Collinearity VIF } \\
\text { (AFVIF) }\end{array}$} & Acceptable if $\leq 5$ & & \\
\hline & & Ideally $\leq 3.3$ & 1.576 & Ideal \\
\hline \multirow{3}{*}{6} & \multirow{3}{*}{ TenenhausGoF (GoF) } & Small $\geq 0.1$ & & \\
\hline & & Medium $\geq 0.25$ & & \\
\hline & & Large $\geq 0.36$ & 0.689 & Large \\
\hline \multirow[t]{2}{*}{7} & \multirow{2}{*}{$\begin{array}{l}\text { Simpson's paradox } \\
\text { ratio (SPR) }\end{array}$} & Acceptable if $\geq 0.7$ & 0.667 & $\begin{array}{l}\text { Approaching } \\
\text { acceptable }\end{array}$ \\
\hline & & Ideally $=1$ & & \\
\hline \multirow{2}{*}{8} & \multirow{2}{*}{$\begin{array}{l}\text { R-squared contribution } \\
\text { ratio (RSCR) }\end{array}$} & Acceptable if $\geq 0.9$ & 0.973 & Accepted \\
\hline & & Ideally $=1$ & 1 & Ideal \\
\hline 9 & $\begin{array}{l}\text { Statistical suppression } \\
\text { ratio (SSR) }\end{array}$ & Acceptable if $\geq 0.7$ & 1 & Accepted \\
\hline 10 & $\begin{array}{l}\text { Nonlinear- bivariate } \\
\text { causality- direction } \\
\text { ratio (NLBCDR) }\end{array}$ & Acceptable if $\geq 0.7$ & 0.750 & Accepted \\
\hline
\end{tabular}

Table 4. R-squared coefficients, Adjusted R-squared coefficients, Q-squared coefficients

\begin{tabular}{|l|c|c|c|}
\hline Latent Variables & $\begin{array}{c}\text { R-squared } \\
\text { coefficients }\end{array}$ & $\begin{array}{c}\text { Adjusted R-squared } \\
\text { coefficients }\end{array}$ & $\begin{array}{c}\text { Q-squared } \\
\text { coefficients }\end{array}$ \\
\hline $\begin{array}{l}\text { Job Satisfaction } \\
\text { (M) }\end{array}$ & 0.357 & 0.354 & 0.368 \\
\hline Performance (Y) & 0.805 & 0.803 & 0.806 \\
\hline
\end{tabular}


International Journal of Business Management and Economic Review

Vol. 4, No. 04; 2021

ISSN: 2581-4664

\section{Results of 1st Hypothesis Analysis (H1)}

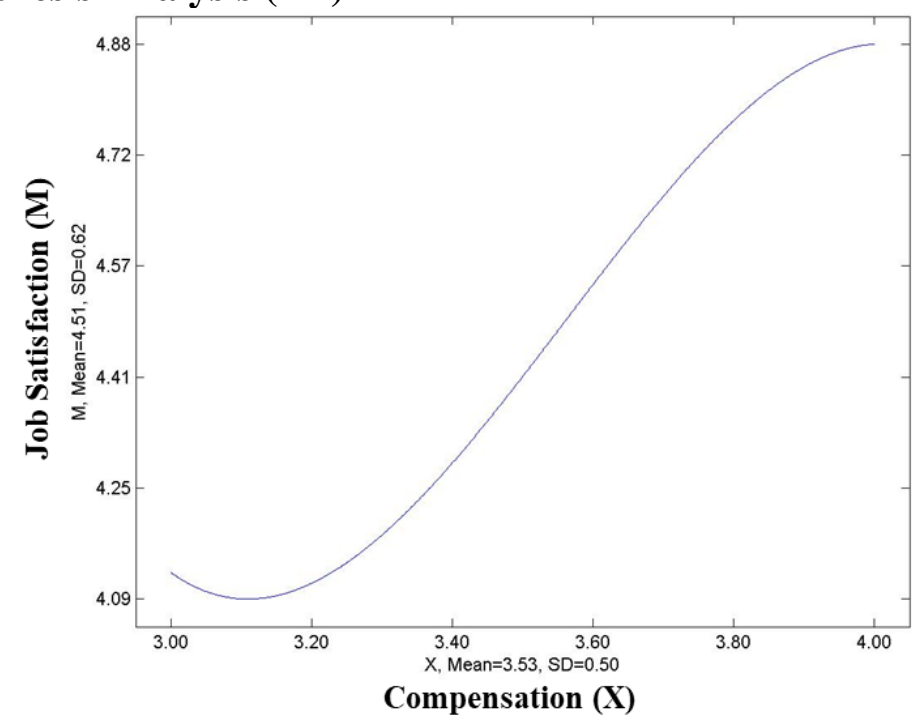

Figure 3. The best-fitting curve for a multivariate relationship between Compensation (X) with Job Satisfaction (M)

The relationship between Compensation (X) to Job Satisfaction (M) is Positive $(\beta=0.57)$ and Significant $(\mathrm{p}<0.001)$. This result can be concluded and proven empirically also statistically, that the greater the Complement given will lead to greater Job Satisfaction in employees.

\section{Results of the Second Hypothesis Analysis (H2)}

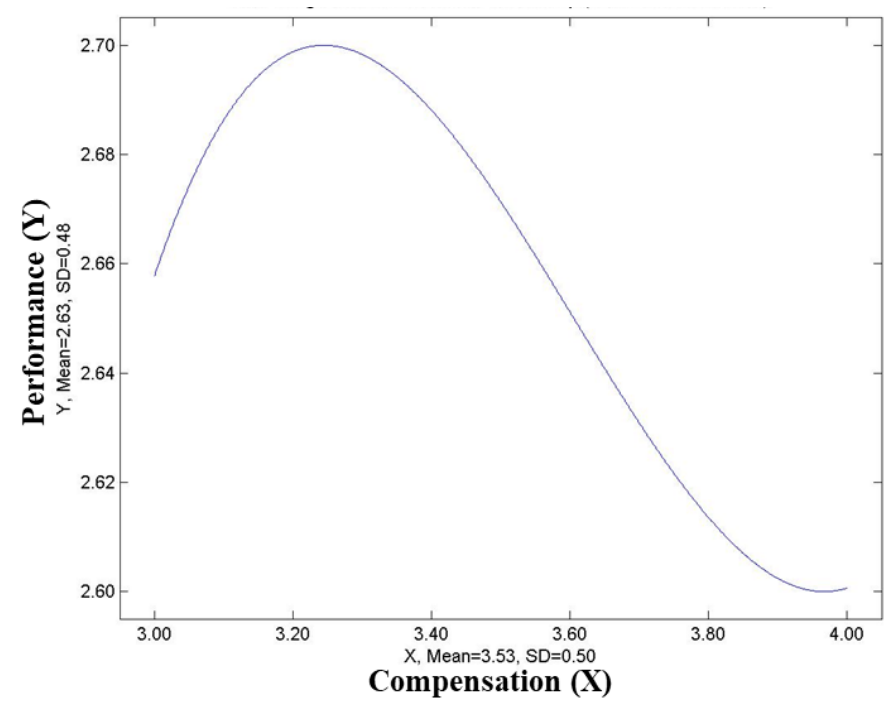


Figure 4. The best-fitting curve for a multivariate relationship between Compensation (X) with Performance (Y)

The relationship between Compensation $(\mathrm{X})$ to Performance $(\mathrm{Y})$ modeled this study: first, the relationship is positive and significant $(\beta=0.44, p<0.001)$, but after there is a mediation role of Job Satisfaction (M), then the relationship between Compensation (X) to Performance ( $\mathrm{Y}$ ) is Negative and insignificant $(\beta=-0.075, p=0.114)$. From the results of this analysis, that the more significantCompensation (X) received by in Samarinda city government environment, inthe early stages there is a performance improvement, but the more significantCompensation (X) given, resulting in a decrease in Performance (Y).

\section{Results of the Third Hypothesis Analysis (H3)}

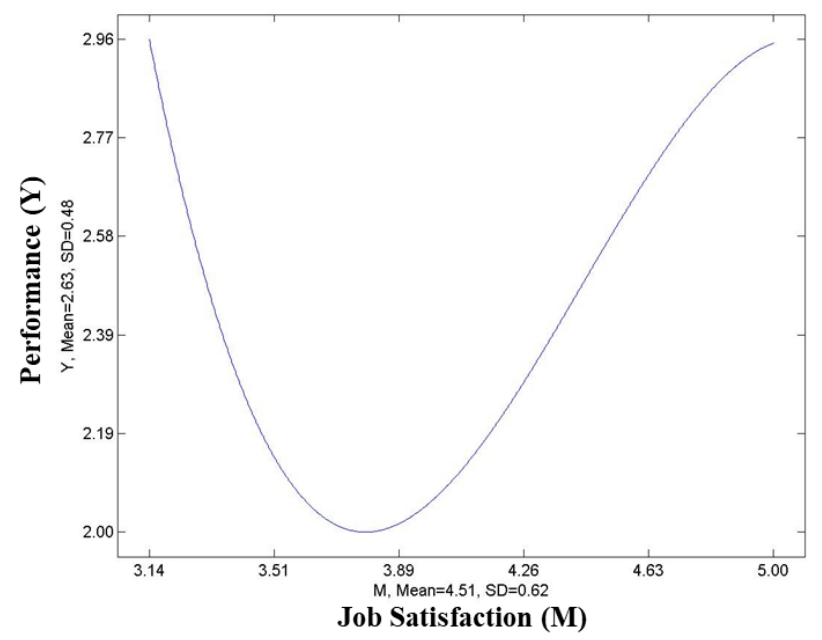

Figure 5.The best-fitting curve for a multivariate relationship between Job Satisfaction (M) with Performance (Y)

Contrary to the results of the analysis of Compensation Relationship (X) to Performance (Y) with the results of the analysis of the relationship of Job Satisfaction (M) with Performance (Y), the results of the analysis are empirically and statistically proven, that the relationship is Positive and very Significant $(\beta=0.936, p<0.001)$. Figure 5 proven that in the early stages of greater Job Satisfaction (M), there will be a decrease and Performance (Y). However, at a later stage, there is a turning point. Resulting in greater Job Satisfaction (M), there will be an increase in Performance (Y) in employees.

Fourth Hypothesis Analysis Results (H4) 
International Journal of Business Management and Economic Review

Vol. 4, No. 04; 2021

ISSN: 2581-4664

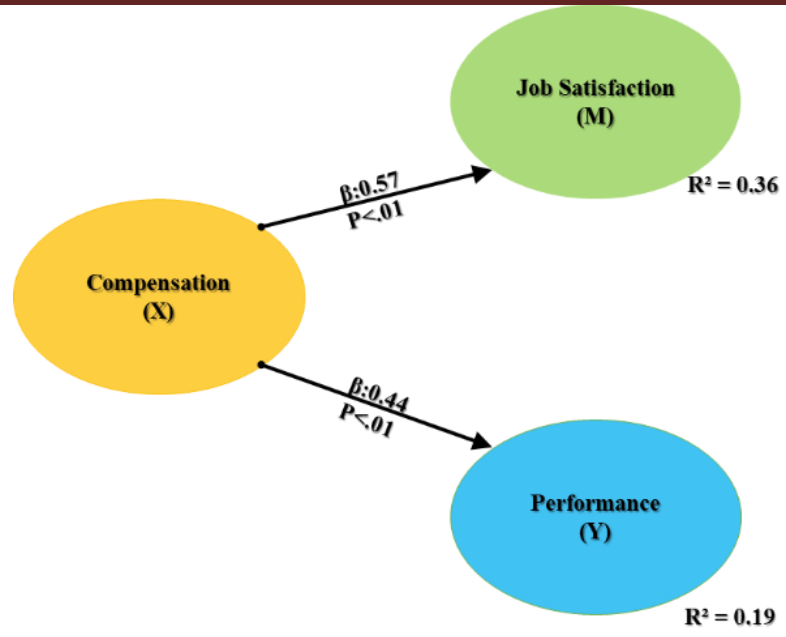

Figure 6. Before mediated by Job Satisfaction

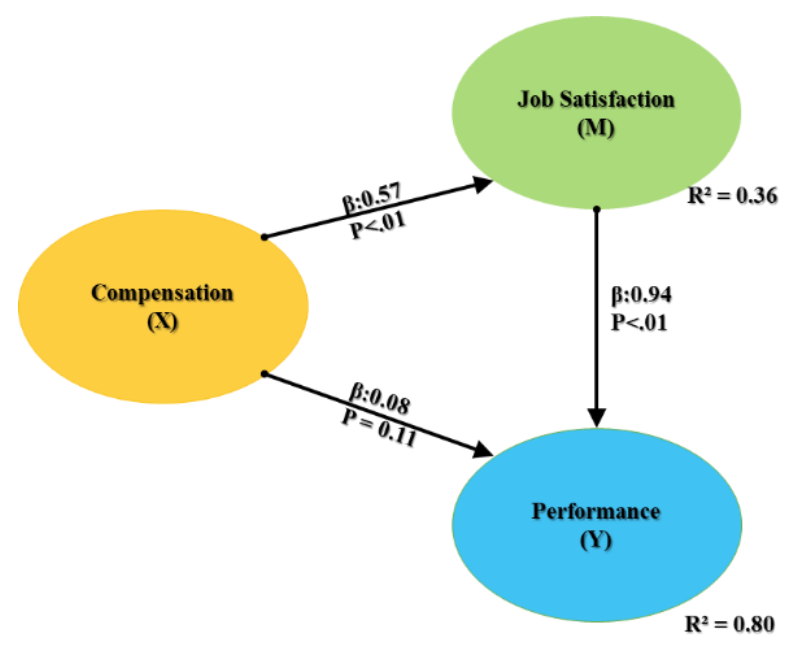

Figure 7. After Job Satisfaction Mediated

The mediation role of Job Satisfaction (M) to the relationship between Compensation (M) and Performance (Y) can be analyzed by looking at Figure 6 and Figure 7. In Figure 6, it appears that the relationship between Compensation (X) and Performance is Positive and Significant ( $\beta$ $=0.44, \mathrm{p}<0.001)$. In Figure 7, it appears that, after the role of Complete Mediation of Job Satisfaction (M), it can see that the relationship of Compensation (X) with performance becomes 
International Journal of Business Management and Economic Review

Vol. 4, No. 04; 2021

ISSN: 2581-4664

negative and insignificant $(\beta=-0.08, \mathrm{p}=0.11)$.

\section{CONCLUSION}

From the overall model analysis results, it can conclude that there is a Complete Mediation Role of Job Satisfaction to the relationship between Compensation and Performance.

The Research Model can produce a Coefficient of Determination of Performance of 0.80, and this means Variable Compensation and Job Satisfaction of employees can explain their Performance by $80 \%$. In contrast, the rest $(20 \%)$ are variables outside the research and error factor.

Job Satisfaction of Employees in the Regional Education and Training Staffing Agency, Regional Research and Development Agency, Regional Development Planning Agency, Regional Revenue Agency, Regional Finance, and Asset Agency and National Unity and Political Agency in Samarinda city government environment, can be explained by Variable Compensation of $36 \%$.

The theoretical implication of this study is that there are other factors besides Compensation for Job Satisfaction. The performance also has other factors besides Compensation and Job Satisfaction and the mediation role of Job Satisfaction.

The practical implications of this study are as a reference for policymakers in determining Compensation Policies for employees so as not to make compensation a weakening factor or factor that results in a decrease in performance.

\section{REFERENCES}

Ajzen, I. (1991). The theory of planned behavior. Organizational Behavior and Human Decision Processes. https://doi.org/10.1016/0749-5978(91)90020-T

Baledi, M., \& Saed, R. A. (2017). The Impact of Compensation on Improving Employees Performance Through Job Satisfaction in Jordanian Newspaper. International Journal of Business Quantitative Economics and Applied Management Research, 4(5).

Barasa, L., Gunawan, A., \& Bambang Sumali. (2018). Determinants of Job Satisfaction and its Implication on Employee Performance of Port Enterprises in DKI Jakarta. International Review of Management and Marketing, 8(5).

Bies, R. J., \& Organ, D. W. (1989). Organizational Citizenship Behavior: The Good Soldier Syndrome. The Academy of Management Review, 14(2). https://doi.org/10.2307/258426

Cedaryana, Luddin, M. R., \& Supriyati, Y. (2018). Influence of Work Discipline, Career Development and Job Satisfaction on Employee Performance Directorate General Research and Development of Ministry Research, Technology and Higher Education. International Journal of Scientific Research and Management, 6(02). https://doi.org/10.18535/ijsrm/v6i2.el02

Gong, T., \& Yang, S. L. (2019). Controlling Bureaucratic Corruption. In Oxford Research Encyclopedia of Politics. https://doi.org/10.1093/acrefore/9780190228637.013.1463

Herawaty, H. (2018). Good Governance and Strengthening the Management of Civil Servants Towards to World Class Bureaucracy. Papua Law Journal, 2(1). https://doi.org/10.31957/plj.v2i1.596 


\section{International Journal of Business Management and Economic Review}

Vol. 4, No. 04; 2021

ISSN: 2581-4664

Indrasari, M., Syamsudin, N., Purnomo, R. B., \& Yunus, E. (2019). Compensation, organizational communication, and career path as determinants of employee performance improvement. Humanities and Social Sciences Reviews, 7(4). https://doi.org/10.18510/hssr.2019.74130

Kock, N. (2010). Regressing WarpPLS in e-collaboration studies: An overview of five main analysis steps. International Journal of E-Collaboration, 6(4), 1-11. https://doi.org/10.4018/jec.2010100101

Kock, N. (2014). Advanced Mediating Effects Tests, Multi-Group Analyses, and Measurement Model Assessments in PLS-Based SEM. International Journal of E-Collaboration, 10(1), 1-13. https://doi.org/10.4018/ijec.2014010101

Kock, N. (2015a). A note on how to conduct a factor-based PLS-SEM analysis. International Journal of E-Collaboration, 11(3), 1-9. https://doi.org/10.4018/ijec.2015070101

Kock, N. (2015b). PLS-based SEM Algorithms: The Good Neighbor Assumption, Collinearity, and Nonlinearity. Information Management and Business Review, 7(2), 113-130. https://doi.org/10.22610/imbr.v7i2.1146

Kock, N. (2015c). Wheat flour versus rice consumption and vascular diseases: Evidence from the China Study II data. Cliodynamics, 6(2), 130-146. https://doi.org/10.21237/C7CLIO6227969

Muna, A. A., Zain, A. A., \& Shaju, G. D. (2017). Job Satisfaction and Employee Performance: a Theoretical Review of the Relationship Between the Two Variables. International Journal of Advanced Research, 943(1).

Nanda, A. A. W. V., Nyoman Gde Dewa Rucika, Mahendra Adi Winatha, \& Hilda Apriani. (2020). THE EFFECT OF DIRECT COMPENSATION TOWARDS EMPLOYEE PERFORMANCE IN THE FRONT OFFICE DEPARTMENT AT ST. REGIS BALI RESORT. Barista : Jurnal Kajian Bahasa Dan Pariwisata, 7(1). https://doi.org/10.34013/barista.v7i1.171

Rosalia, P. D., Mintarti, S., \& Heksarini, A. (2020). The Effect of Compensation and Motivation on Job Satisfaction and Employee Performance at SMK Medika Samarinda. Saudi Journal of Business and Management Studies, 5(7). https://doi.org/10.36348/sjbms.2020.v05i07.009

Saputra, P., Sudiro, A., Irawanto, D. W., \& Idris, I. (2018). Job satisfaction in Compensation, environment, discipline, and Performance: evidence from Indonesia higher education. Management and Economics Journal (MEC-J). https://doi.org/10.18860/mec-j.v0i0.5611

Sherly, S., Lie, D., Candra, V., Siallagan, D. M., \& Sudirman, A. (2021). Interpretation of the Effects of Job Satisfaction Mediation on the Effect of Principal Supervision and Compensation on Teacher Performance. Journal of Educational Science and Technology (EST), 7(1). https://doi.org/10.26858/est.v7i1.19208 